Article

\title{
'Frontenac' Grape Response to Canopy Management in North Dakota
}

\author{
Brittany Korynta Olson ${ }^{1,2}$, Matthew Brooke ${ }^{2,3}$, Zhuoyu Wang ${ }^{2}$, Andrej Svyantek ${ }^{2,4}$, John Stenger 5 \\ and Harlene Hatterman-Valenti ${ }^{2, *(1)}$
}

check for updates

Citation: Olson, B.K.; Brooke, M.; Wang, Z.; Svyantek, A.; Stenger, J.; Hatterman-Valenti, H. 'Frontenac' Grape Response to Canopy Management in North Dakota. Horticulturae 2021, 7, 288. https:// doi.org/10.3390/horticulturae7090288

Academic Editor: Sergio Ruffo Roberto

Received: 27 June 2021

Accepted: 30 August 2021

Published: 3 September 2021

Publisher's Note: MDPI stays neutral with regard to jurisdictional claims in published maps and institutional affiliations.

Copyright: (c) 2021 by the authors. Licensee MDPI, Basel, Switzerland. This article is an open access article distributed under the terms and conditions of the Creative Commons Attribution (CC BY) license (https:/ / creativecommons.org/licenses/by/ $4.0 /)$.
1 KLN Family Brands, 400 Lakeside Dr, Perham, MN 56573, USA; brittany.korynta@gmail.com

2 Department of Plant Sciences, North Dakota State University, NDSU Department 7670, P.O. Box 6050, Fargo, ND 58108, USA; matthew.brooke@wsu.edu (M.B.); zhuoyu.wang@ndsu.edu (Z.W.); andrej.svyantek@okstate.edu (A.S.)

3 Department of Crop and Soil Sciences, Washington State University, 291-D Johnson Hall, P.O. Box 646420, Pullman, WA 99164, USA

4 Department of Horticulture and Landscape Architecture, Oklahoma State University, 358 Agricultural Hall, Stillwater, OK 74078, USA

5 Department of Agricultural and Biosystems Engineering, North Dakota State University, NDSU Department 7620, P.O. Box 6050, Fargo, ND 58108, USA; john.stenger@ndus.edu

* Correspondence: h.hatterman.valenti@ndsu.edu

\begin{abstract}
Experiments were conducted in 2013 and 2014 to evaluate the effects of training system and leaf removal treatments on yield and quality for 'Frontenac', an interspecific hybrid wine grape, at a research vineyard located near Absaraka, North Dakota. The experiment was structured as a randomized complete block design with a split-plot arrangement including four training system treatments (Geneva Double Curtain (GDC), High Cordon (HC), Vertical Shoot Positioned (VSP), Four-Arm Kniffin (4AK)), and four-leaf removal timing treatments (bloom, post-bloom, veraison, and a control, no removal) with eight replicates. In 2013, 1428 growing degree days (GDDs) accumulated in the 155 days between frost events. In 2014, 1156 GDDs accumulated in the 121 days between frost events, 272 GDDs less than the year prior. Even with the large GDD differences between years, there was no significant interaction between trellis type and leaf removal, and the main factor of leaf removal did not influence any of the fruit variables where data were collected. Combined data analysis showed no significant differences in fruit juice total soluble solids (TSS) or titratable acidity (TA). The fruit juice $\mathrm{pH}$ in 2013 was greater when grapes were grown in the VSP system compared to grapes grown in the other trellis systems. In 2014, live nodes and total shoots were greater for grapes grown on GDC and 4AK systems compared to grapes grown on the HC and VSP systems. Additionally, in 2014, grapes grown on the GDC system had a greater cluster number and yield when compared to grapes grown on the 4AK or VSP systems. These findings suggest that 'Frontenac' fruit TSS accumulation and TA were not affected by leaf removal or trellis system in North Dakota vineyards and that yield gains may be reached due to the training system without negatively affecting fruit quality.
\end{abstract}

Keywords: cold-hardy grapevine; hybrid wine grape; trellis system

\section{Introduction}

The recent and rapid expansion of the grape and wine industry in North Dakota was made possible by the development and release of interspecific Vitis spp. hybrids during the 1990s. 'Frontenac', an interspecific hybrid with $V$. riparia parentage, was released from the University of Minnesota in 1996. 'Frontenac' is currently one of the most common wine grape cultivars in the Upper Midwest [1] due to its cold hardiness and productivity. However, 'Frontenac' challenges winemakers due to high acidity and low $\mathrm{pH}$, which leads to a different acid profile compared to traditional $V$. vinifera cultivars [2-5]. Work with $V$. vinifera has demonstrated that increased irradiance within the fruiting zone can improve 
fruit quality [6-8]. However, interspecific hybrids with $V$. riparia lineage may respond differently to canopy management practices.

Grapevine training systems manipulate vine form and contribute to differences in total leaf area, the percentage of leaf area well-exposed to light, and the percentage of leaves located in the interior of the canopy [9-12]. Consequently, a grapevine's capacity to photosynthesize efficiently depends upon its training system and the accompanying light microclimate of its leaves [10]. Modifications in training may increase the amount of leaf area exposed to high-intensity direct radiation while also increasing the interception of diffuse radiation, thus improving the radiation microclimate of the remaining foliage [13-15]. In addition, training may impact numerous other variables such as fruit bud differentiation, cluster exposure, vine water status, and leaf transpiration [10].

Furthermore, a training system structure that maximizes fruit sunlight exposure, especially in cool climates, may be used to optimize berry growth and composition. Fruit in exposed portions of the canopy generally exhibit higher concentrations of sugars, anthocyanins, and total phenolics, as well as lower levels of malic acid, potassium, and juice $\mathrm{pH}$ compared to shaded fruits [16]. With the appropriate choice of training system, increases in yield and alterations to fruit composition and/or wine sensory have been reported [17-25].

Contrastingly, other researchers have failed to identify differences in fruit or wine composition directly attributable to training system selection [26-32]. Martinson and Particka stated that maintaining cluster exposure and avoiding shading may be more important than the training system based on work at Clayton, NY on 'Frontenac' [33]. Multiple studies indicate shaded canopies produce fruit with lower sugar concentration and increased $\mathrm{pH}$ and TA content [34-36]. Therefore, excessively shaded fruits may have compromised composition. The decreased sugar content for shaded fruit may result from a combination of a delay in maturation, or lower light intensity on source leaves, and lower berry temperature $[13,37,38]$.

Decreased $\mathrm{pH}$ levels for shaded berries have been associated with the higher fruit concentrations of nitrates and potassium; low light wavelengths $(600 \mathrm{~nm}$ to $730 \mathrm{~nm})$ in the canopy reduces the activity of the enzyme nitrate reductase leading to an accumulation of nitrate and potassium [11,39]. High TA levels in shaded fruit were attributed to a reduction in malate degradation associated with reduced berry temperature $[38,40-42]$. Excessive shade also produces fruit with reduced aromatic, anthocyanin, and monoterpene levels $[7,8]$.

Fruit zone leaf removal is one of the most frequently applied summer canopy management practices in grape growing $[17,38,39,43]$. Leaf removal is traditionally conducted between fruit set and veraison; however, early leaf removal is conducted as early as prebloom to fruit set [17]. Early leaf removal is the removal of basal leaves of the main shoots, and occasionally, lateral shoots developed from the basal nodes. Increasingly, work is focusing on early leaf removal practices as a potential alternative to cluster thinning [44,45]. Benefits of early leaf removal include reducing the severity of Botrytis rot infection, altering flower development, and modulating fruit and wine composition [9,43,46,47]. The improved microclimate following leaf removal may influence the berry epidermis, contributing to higher anthocyanin concentrations in wine. Further, wine volatile components are increased by early leaf removal under warm climatic conditions [48]. Leaf removal effects are dependent on the cultivar, timing, severity, and climate $[39,49,50]$.

Previously, research on leaf removal impact demonstrates its variable effect on fruit quality and yield. Leaf removal on 'Sauvignon Blanc' from fruit set to veraison with various defoliation rates was found to effectively reduce TA, malic acid, $\mathrm{pH}$, and juice potassium in all leaf removal treatments with no effect on yield [39]. Similar results found decreases in $\mathrm{TA}, \mathrm{pH}$, and potassium with basal leaf removal treatments on $V$. vinifera cultivars Bacchus, Pearl of Csaba, Schönburger, and Siegerrebe near veraison [50]. Basal leaf removal, in $V$. vinifera cultivars Graciano and Carignan, at fruit set resulted in decreased malic acid concentration [51]. Interestingly, defoliation of six basal leaves per shoot pre-bloom in 'Sangiovese' caused a decrease in yield, yet increased soluble solids, total anthocyanins, 
and TA [49]. Hence, not all attempts to advance maturity or improve grape composition with leaf removal have been successful [52-54]. Work performed by Percival, Fisher, and Sullivan (1994) in the Niagara region of Canada reported on leaf removal before veraison on $V$. vinifera and found no difference in $\mathrm{SS}, \mathrm{pH}$, and $\mathrm{TA}$, and no reduction in yield [38].

Leaf removal effects can be cultivar-dependent. Three $V$. vinifera cultivars were compared by leaf removal treatments over 4 years [55]. The cultivar Barbera had no significant differences in TA and $\mathrm{pH}$, while cultivars Croatina and Malvasia di Candia aromatica had significant differences in TA [55]. A report by Portz et al. (2010) on 'Frontenac Gris' in Iowa found no significant differences in SS, $\mathrm{pH}$, and TA with leaf removal conducted in early July [56]. Similarly, leaf removal at veraison on 'Frontenac' by Wlordachak et al. (2009) in Illinois found no significant differences in SS, TA, and pH in leaf removal treatments. Therefore, it is of great importance to research leaf removal treatment during bloom, post-bloom, and veraison compared to no leaf removal treatment in North Dakota-specific environments [57].

The effect of leaf removal on fruit quality and yield is dependent on timing, severity, climate, and cultivar; therefore, it is necessary to conduct experiments on specific cultivars within specific climates to tailor regional best management practices. The objectives of this experiment were to evaluate the effects of training systems and fruit zone leaf removal timings on 'Frontenac' grapevines' fruit composition and vine performance in eastern North Dakota. The effects of these practices are valuable and necessary for growers and winemakers in the Upper Midwest grape and wine regions.

\section{Materials and Methods}

\subsection{Experimental Site and Design}

The University of Minnesota interspecific hybrid, 'Frontenac', was used to study the effects of training systems and leaf removal on vine performance and fruit composition over two years, 2013 and 2014. The research vineyard used was located at the North Dakota State University (NDSU) research station near Absaraka, ND, USA (Lat: 46 $59^{\prime} 22.0986^{\prime \prime}$ Long: $-97^{\circ} 21^{\prime} 22.2222^{\prime \prime}$ ). Soils at the site are Warsing sandy loam, fine-loamy over sandy and sandy-skeletal, mixed, superactive, frigid Oxyaquic Hapludolls with $0-2 \%$ slopes. One hundred twenty-eight own-rooted 'Frontenac' vines were established in 2006 and spaced $2.6 \mathrm{~m}$ apart in rows $3.3 \mathrm{~m}$ apart. Rows were oriented North-South with 32 vines per row.

Weed, disease, and pest control were managed according to North Dakota industry standards. Due to low pressure, no fungicide or insecticide applications were conducted during the experimental period. Weed-free strips ( $0.5 \mathrm{~m}$ wide) were maintained below the vine rows using tillage combined with pre-emerge (Flumioxazin, Chateau ${ }^{\circledR}$, Valent USA, San Ramon, CA, USA) and post-emerge (Glufosinate, Rely ${ }^{\circledR}$, BASF, Florham Park, NJ, USA; Glyphosate, Roundup ${ }^{\circledR}$, Monsanto, St. Louis, MO, USA) herbicide applications. Red fescue (Festuca rubra) was grown between rows as a ground cover. Annual petiole tests were used in the research vineyard to determine fertilizer applications prior to the experiment; no fertility alterations were conducted during the experimental period.

\subsection{Training Systems and Canopy Management}

Vines were originally trained to the Four-Armed-Kniffin (4AK) trellis system. In 2010, vines were retroactively trained to three additional canopy-training systems: Geneva Double Curtain (GDC), High Cordon (HC), and mid-wire with Vertical Shoot Positioning (VSP). Training system treatments were arranged as a randomized complete block design with eight replicates of the four training system treatments and four vines within each training system treatment, resulting in 16 vines per rep and 128 plants total.

Vines in the HC system were trained to bilateral cordons $2 \mathrm{~m}$ aboveground. Cordons extended in opposite directions (North-South). Vines in the 4AK system were trained to two bilateral cordons, one at $2 \mathrm{~m}$ aboveground and the second at $1.5 \mathrm{~m}$ aboveground. Vines in the VSP system were trained to bilateral cordons $1 \mathrm{~m}$ aboveground. Throughout the summer, shoots were tucked upward as needed between horizontally running catch wire. 
GDC vines were trained to two bilateral cordons, each $2 \mathrm{~m}$ aboveground with wires $0.6 \mathrm{~m}$ apart supported by post extensions. Shoots were combed downward three times during the growing season for GDC, $\mathrm{HC}$, and $4 \mathrm{AK}$ vines at three weeks post-bloom, four weeks post-bloom, and veraison.

For plant management, vines were pruned in late spring to delay early bud break and decrease susceptibility to late spring frosts [30,58-60]. Prunings of one-year-old canes were weighed to determine vine size. Balanced pruning was used to maintain a balance between vegetative vigor and reproductive quality. The base node count was 30 with every additional $0.45 \mathrm{~kg}$ of one-year-old pruning wood leading to retention of an additional 10 nodes per vine, with a maximum limit of 60 nodes per vine. Cane pruning weights, cordon lengths, and trunk diameter measurements were taken each spring to determine vine size.

Viable nodes were counted at bud burst. Shoots per node and shoots per plant were counted close to bloom. Shoots were not thinned in an attempt to retain shoots for annual cordon rejuvenation and to reduce gaps between spurs prone to separation. In both years, no cluster thinning was conducted. Shoot tips were only hedged if growth reached the soil surface.

\subsection{Leaf Removal and Light Measurements}

Fruit zone leaf removal treatments were arranged as a split-plot, with training system as the whole-plot and leaf removal as the sub-plot. The four-leaf removal treatments were conducted at bloom, post-bloom, veraison, and no removal (control) (Figure 1). The treatments administered in 2013 were re-administered to the same vines the following growing season, 2014.

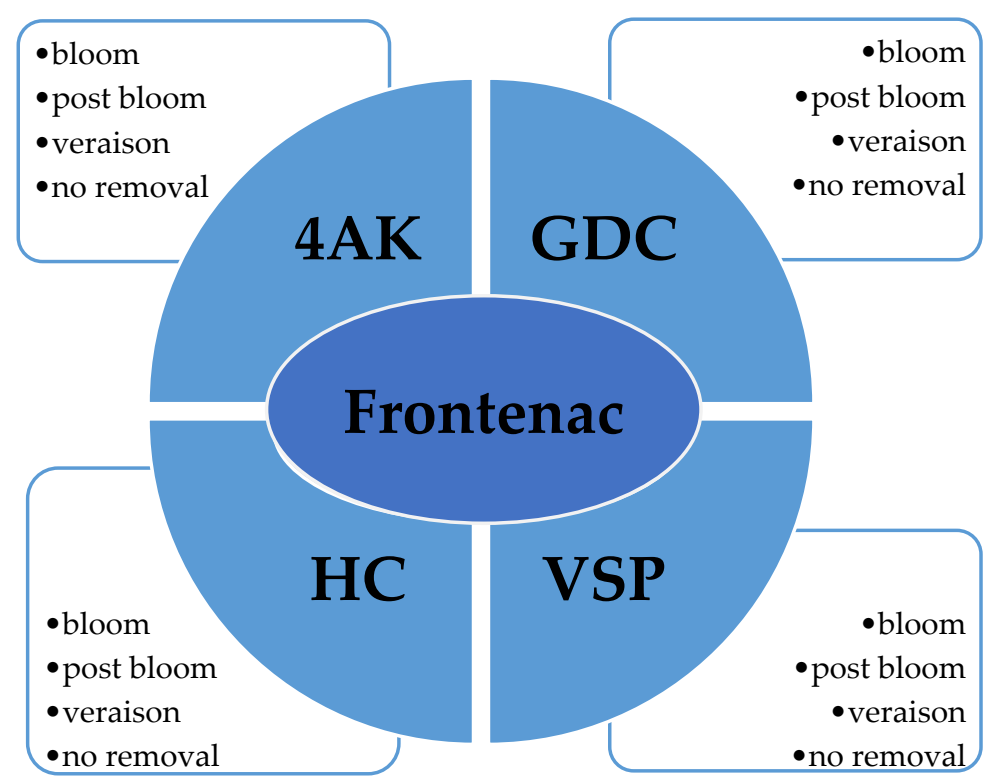

Figure 1. Experimental design of treatments to 'Frontenac' grapevines in Absaraka, North Dakota in 2013 and 2014. HC: High Cordon; GDC: Geneva Double Curtain; VSP: Vertical Shoot Positioning; 4AK: Four-Arm-Kniffin.

Four training systems were evaluated: Four-Arm Kniffin (4AK), Geneva Double Curtain (GD), High Cordon (HC), and Vertical Shoot Positioned (VSP) within each training system, and four-leaf removal treatment subplots were examined, bloom, post-bloom, veraison, and no removal treatment (control).

Canopy density of each training system was maintained during the growing season, with shoot positioning appropriate for each training system. Leaf removal treatments were applied at bloom, three or four weeks post-bloom (once 289 GDDs accumulated 
post-bloom), and veraison. Leaves were removed from the basal three nodes on all shoots arising from the cordon and spurs.

Point quadrant data were collected to supplement the understanding of canopy density. Point quadrant is the use of a thin rode inserted into the fruit zone of the canopy of a single vine 50 times, 25 from each side of the row with the rod parallel to the ground [17]. At the insertion, contacts with leaves and other vine parts are recorded. The data collected give the ability to calculate percent gaps, leaf layer number, percent interior leaves, and percent interior cluster. These values were compared to optimum values to elucidate canopy structure.

\subsection{Harvest Indices and Fruit Composition}

Fruit was sampled weekly from veraison to predict the harvest. At the final sampling date, fruit were harvested and weighed on a per-plant basis for yield results. Cluster weight was determined by weighing a random sample of three clusters per vine. Berry weight and diameter were determined by weighing and measuring a 100-berry sample from the three-cluster sample. Fruit characteristics were determined by a 15-berry sample per vine. Total Soluble Solids (TSS) were measured twice per sample by a portable pocket refractometer (PAL-1, ATAGO, Tokyo, Japan). Juice TA and $\mathrm{pH}$ were measured in triplicate for each experimental unit and were determined using standard methods with an Orion star A111 pH meter (Thermo Scientific, Beverly, MA, USA). The date of harvest each year was determined by inclement weather, availability of vineyard help, and fruit composition.

\subsection{Statistical Analysis}

Data were analyzed across years as a split-plot in time using Proc Mixed SAS statistical analysis software (SAS version 9.3, SAS Institute Inc., Cary, NC, USA). Only the wholeplot main effect, the training system, was significant for variables evaluated. Differences among training systems were determined by pairwise $t$-tests, and the significance of these differences were determined based on a $95 \%$ level of confidence for all comparisons.

\section{Results}

\subsection{Variability between Seasons}

Growing Degree Days (GDD) were calculated for each date using the daily average temperature and a base temperature for grapevine, $10{ }^{\circ} \mathrm{C}$. Between the two growing seasons, there were 272 more GDDs accumulated in 2013 than in 2014 (Table 1). Frost-free days were identified as the number of days between the last frost of spring and the first killing frost of fall. Compared to 2013, with 155 frost-free days, 2014 had 34 few frost-free days. Bud burst occurred in the final days of May in 2013 and 2014, while bloom was six days later in 2013 than 2014. In both years. Veraison occurred in mid-August of both years, while harvest occurred in early October at the threat of fall frost.

Table 1. Climatic and phenological data for 'Frontenac' grape grown in 2014 and 2013 in Absaraka, ND.

\begin{tabular}{cccccccc}
\hline Year & Frost-Free Days $^{\mathbf{z}}$ & $\begin{array}{c}\text { Accumulated } \\
\text { GDDs } \mathbf{y}\end{array}$ & Days till Harvest $^{\mathbf{x}}$ & Bud Burst & Bloom & Veraison & Harvest \\
\hline 2013 & 155 & 1428 & 152 & 29 May & 24 June & 19 August & 10 October \\
2014 & 121 & 1156 & 146 & 27 May & 18 June & 14 August & 8 October \\
\hline
\end{tabular}

${ }^{\mathrm{z}}$ Number of days between last spring frost and first fall frost. ${ }^{\mathrm{y}} \mathrm{GDDs}=$ Growing Degree Days (base $10^{\circ} \mathrm{C}$ ) accumulated in the frost-free period. ${ }^{x}$ Number of days from last frost event till harvest.

\subsection{Training System Effects on Pruning Weights and Node Viability}

In 2013, pruning weights were uniformly under $454 \mathrm{~g}$, and all vines were pruned to as close to 30 nodes as possible (Table 2). Due to extreme winter conditions associated with polar vortex events, including cold temperatures (minimum observed air temperature $-33.9^{\circ} \mathrm{C}$, 2 January 2014), wind storms, and a lack of snow cover in 2014 , bud death was 
documented in many vineyards across the Upper Midwest. To account for possible bud death, additional nodes were retained to increase live node counts. Thus, balanced pruning was conducted with a base node count of 40 in 2014, ten more nodes than in 2013.

Table 2. Effect of training system on average pruning weight and retained nodes per vine for 'Frontenac' grape in 2013 and 2014.

\begin{tabular}{ccccc}
\hline & \multicolumn{2}{c}{ Pruning Mass (g/Vine) } & \multicolumn{2}{c}{ Retained Nodes (no./Vine) } \\
\hline Treatment & $\mathbf{2 0 1 3}$ & $\mathbf{2 0 1 4}$ & $\mathbf{2 0 1 3}$ & $\mathbf{2 0 1 4}$ \\
\hline HC $^{\mathrm{z}}$ & $62 \mathrm{a}$ & $254 \mathrm{c}$ & $28.4 \mathrm{a}$ & $41.3 \mathrm{a}$ \\
GDC & $35 \mathrm{a}$ & $198 \mathrm{c}$ & $28.6 \mathrm{a}$ & $38.5 \mathrm{a}$ \\
VSP & $119 \mathrm{a}$ & $477 \mathrm{a}$ & $29.0 \mathrm{a}$ & $42.9 \mathrm{a}$ \\
4AK & $52 \mathrm{a}$ & $365 \mathrm{~b}$ & $28.6 \mathrm{a}$ & $41.0 \mathrm{a}$ \\
\hline
\end{tabular}

${ }^{z}$ HC: High Cordon; GDC: Geneva Double Curtain; VSP: Vertical Shoot Positioning; 4AK: Four-Arm-Kniffin y Means followed by the same letter within each column are not significantly different according to a pairwise $t$-test $(p \leq 0.05)$.

In 2014, vines on VSP produced the greatest pruning weight with $477 \mathrm{~g} /$ vine. Vines on 4AK followed vines on VSP with $365 \mathrm{~g} /$ vine in 2014. Due to the lack of developed wood for retention, no significant differences among retained nodes were found between training systems in either year.

In 2013, no significant difference in viable nodes or node mortality among different training systems was identified (Table 3). In 2014, following harsh weather, vines on GDC and 4AK had significantly more live nodes compared to vines on HC and VSP. The VSP vines had the greatest number of dead nodes followed by HC, 4AK, and GDC vines sequentially.

Table 3. Effect of training system on average node viability post pruning per vine on 'Frontenac' grape in 2013 and 2014.

\begin{tabular}{ccccc}
\hline & \multicolumn{2}{c}{ Live Nodes (no./Vine) } & \multicolumn{2}{c}{ Dead Nodes (no./Vine) } \\
\hline Treatment & $\mathbf{2 0 1 3}$ & $\mathbf{2 0 1 4}$ & $\mathbf{2 0 1 3}$ & $\mathbf{2 0 1 4}$ \\
\hline HC $\mathrm{z}$ & $19.0 \mathrm{a} \mathrm{y}$ & $17.8 \mathrm{~b}$ & $9.4 \mathrm{a}$ & $22.6 \mathrm{~b}$ \\
GDC & $20.0 \mathrm{a}$ & $23.9 \mathrm{a}$ & $8.5 \mathrm{a}$ & $16.3 \mathrm{c}$ \\
VSP & $20.6 \mathrm{a}$ & $15.0 \mathrm{~b}$ & $8.7 \mathrm{a}$ & $28.4 \mathrm{a}$ \\
4AK & $21.1 \mathrm{a}$ & $22.6 \mathrm{a}$ & $7.4 \mathrm{a}$ & $19.4 \mathrm{bc}$ \\
\hline
\end{tabular}

${ }_{\mathrm{z}}$ HC: High Cordon; GDC: Geneva Double Curtain; VSP: Vertical Shoot Positioning; 4AK: Four-Arm-Kniffin $\mathrm{y}$ Means followed by the same letter within each column are not significantly different according to a pairwise $t$-test $(p \leq 0.05)$.

\subsection{Training System Effects on Canopy}

Point quadrant data showed no differences in canopy density (Table A1). Additionally, shoots per meter of cordon data were calculated from total cordon length and total shoot number. Results suggest that in both years, vines on the $4 \mathrm{AK}$ trellis had a greater cordon length compared to vines on VSP and HC trellises (Table 4). Further, 4AK vines had significantly fewer shoots per meter compared to vines on GDC and HC trellises in both years. 
Table 4. Effect of training system on average cordon length and average shoots per meter in 'Frontenac' grape.

\begin{tabular}{ccccc}
\hline & \multicolumn{2}{c}{ Cordon Length $(\mathbf{m})$} & \multicolumn{2}{c}{ Shoots per Meter } \\
\hline Treatment & $\mathbf{2 0 1 3}$ & $\mathbf{2 0 1 4}$ & $\mathbf{2 0 1 3}$ & $\mathbf{2 0 1 4}$ \\
\hline HC $^{\mathrm{z}}$ & $1.83 \mathrm{c}$ & $1.78 \mathrm{c}$ & $11.9 \mathrm{a}$ & $19.9 \mathrm{a}$ \\
GDC & $2.54 \mathrm{ab}$ & $2.42 \mathrm{ab}$ & $11.7 \mathrm{a}$ & $17.7 \mathrm{ab}$ \\
VSP & $2.30 \mathrm{bc}$ & $2.00 \mathrm{bc}$ & $9.4 \mathrm{ab}$ & $14.6 \mathrm{bc}$ \\
4AK & $2.97 \mathrm{a}$ & $2.84 \mathrm{a}$ & $8.1 \mathrm{~b}$ & $13.1 \mathrm{c}$ \\
\hline
\end{tabular}

${ }^{\mathrm{z}}$ HC: High Cordon; GDC: Geneva Double Curtain; VSP: Vertical Shoot Positioning; 4AK: Four-Arm-Kniffin

y Means followed by the same letter within each column are not significantly different according to a pairwise $t$-test $(p \leq 0.05)$.

\subsection{Training System Effect on Vine Yield}

There were no significant differences among treatments for shoot number, cluster number, cluster weight, or yield in 2013 (Table 5). In 2014, VSP vines had significantly lower shoot numbers and cluster numbers, whereas GDC and 4AK vines had more shoots and clusters. There were no differences in cluster weights. The yield in 2014 ranged from 2.627 (GDC) to $1.160 \mathrm{~kg}$ (VSP). Yield components berry number, berry weight, and berry diameter did not differ among trellis systems in either year.

Table 5. Effect of training system on yield components and berry characteristics in 'Frontenac' grape.

\begin{tabular}{|c|c|c|c|c|c|c|c|c|c|c|c|c|c|c|}
\hline \multirow[b]{2}{*}{ Treatment } & \multicolumn{2}{|c|}{$\begin{array}{c}\text { Shoot } \\
\text { Number/Vine }\end{array}$} & \multicolumn{2}{|c|}{$\begin{array}{c}\text { Cluster } \\
\text { Number/Vine }\end{array}$} & \multicolumn{2}{|c|}{$\begin{array}{l}\text { Single Cluster } \\
\text { Weight (g) }\end{array}$} & \multicolumn{2}{|c|}{ Yield (kg/Vine) } & \multicolumn{2}{|c|}{$\begin{array}{l}\text { Berry Count } \\
\text { (no./Cluster) }\end{array}$} & \multicolumn{2}{|c|}{$\begin{array}{c}\text { Single } \\
\text { Berry } \\
\text { Weight (g) }\end{array}$} & \multicolumn{2}{|c|}{$\begin{array}{c}\text { Single } \\
\text { Berry } \\
\text { Diameter } \\
\text { (cm) }\end{array}$} \\
\hline & 2013 & 2014 & 2013 & 2014 & 2013 & 2014 & 2013 & 2014 & 2013 & 2014 & 2013 & 2014 & 2013 & 2014 \\
\hline $\mathrm{HC}^{\mathrm{z}}$ & $20.9 \mathrm{a}^{\mathrm{y}}$ & $33.0 \mathrm{~b}$ & $24.5 \mathrm{a}$ & $26.2 \mathrm{~b}$ & $52.76 \mathrm{a}$ & $82.57 \mathrm{a}$ & $1.39 \mathrm{a}$ & $1.94 \mathrm{ab}$ & $65.9 \mathrm{a}$ & $74.4 \mathrm{a}$ & $0.79 \mathrm{a}$ & $1.10 \mathrm{a}$ & $1.1 \mathrm{a}$ & $1.1 \mathrm{a}$ \\
\hline GDC & $21.4 \mathrm{a}$ & $41.4 \mathrm{a}$ & $17.8 \mathrm{a}$ & $35.4 \mathrm{a}$ & $40.21 \mathrm{a}$ & $79.32 \mathrm{a}$ & $0.83 \mathrm{a}$ & $2.63 \mathrm{a}$ & $52.7 \mathrm{a}$ & $75.0 \mathrm{a}$ & $0.74 \mathrm{a}$ & $1.05 \mathrm{a}$ & $1.0 \mathrm{a}$ & $1.1 \mathrm{a}$ \\
\hline VSP & $21.8 \mathrm{a}$ & $23.9 c$ & $18.8 \mathrm{a}$ & $16.1 \mathrm{c}$ & $51.34 \mathrm{a}$ & $73.76 \mathrm{a}$ & $1.16 \mathrm{a}$ & $1.17 \mathrm{c}$ & $63.1 \mathrm{a}$ & $67.9 \mathrm{a}$ & $0.80 \mathrm{a}$ & $1.08 \mathrm{a}$ & $1.0 \mathrm{a}$ & $1.1 \mathrm{a}$ \\
\hline $4 \mathrm{AK}$ & $23.3 \mathrm{a}$ & $40.1 \mathrm{a}$ & $26.3 \mathrm{a}$ & $25.2 \mathrm{~b}$ & $47.52 \mathrm{a}$ & $82.94 \mathrm{a}$ & $1.37 \mathrm{a}$ & $1.92 \mathrm{~b}$ & $59.9 \mathrm{a}$ & $74.2 \mathrm{a}$ & $0.77 \mathrm{a}$ & $1.11 \mathrm{a}$ & $1.0 \mathrm{a}$ & $1.1 \mathrm{a}$ \\
\hline
\end{tabular}

${ }^{\mathrm{z}}$ HC: High Cordon; GDC: Geneva Double Curtain; VSP: Vertical Shoot Positioning; 4AK: Four-Arm-Kniffin. ${ }^{\mathrm{y}}$ Means followed by the same letter within each column are not significantly different according to a pairwise $t$-test $(p \leq 0.05)$.

Ravaz Index (RI) values (yield from year ${ }_{a}$ / pruning mass during the dormant season of year ${ }_{a+1}$ ) indicated vines were potentially under-cropped. For the 2013 season, RI values ranged from 2.4 (VSP) to 5.5 (HC), and in 2014 the RI values ranged from 0.9 (VSP) to 4.7 (GDC) (data not shown). For both seasons, VSP vines had the lowest RI. This may be driven by the higher pruning masses observed for VSP vines with no observed increase in yield.

\subsection{Training System Effects on Fruit Characteristics}

In 2013, VSP vine fruit had the highest $\mathrm{pH}$ (Table 6). TSS ranged from 27.2 to $28.5 \mathrm{Brix}$ in 2013 and 24.9 to 25.8 Brix in 2014. TA was lower in 2013, ranging from 11.68 to $12.01 \mathrm{~g} / \mathrm{L}$, while in 2014, TA was above $17 \mathrm{~g} / \mathrm{L}$ for all treatments. TSS and TA were not altered by the training system in either year.

Table 6. Effect of training systems on $\mathrm{pH}$, total soluble solids, and titratable acidity in 'Frontenac' grape.

\begin{tabular}{ccccccc}
\hline & \multicolumn{2}{c}{$\mathbf{p H}$} & \multicolumn{2}{c}{ Total Soluble Solids (Brix) } & \multicolumn{2}{c}{ Titratable Acidity (g/L) } \\
\hline Treatment & $\mathbf{2 0 1 3}$ & $\mathbf{2 0 1 4}$ & $\mathbf{2 0 1 3}$ & $\mathbf{2 0 1 4}$ & $\mathbf{2 0 1 3}$ & $\mathbf{2 0 1 4}$ \\
\hline HC $^{\mathrm{z}}$ & $3.20 \mathrm{~b} \mathrm{y}^{\mathrm{y}}$ & $3.04 \mathrm{a}$ & $27.9 \mathrm{a}$ & $25.7 \mathrm{a}$ & $12.01 \mathrm{a}$ & $17.19 \mathrm{a}$ \\
GDC & $3.24 \mathrm{~b}$ & $3.02 \mathrm{a}$ & $28.5 \mathrm{a}$ & $25.8 \mathrm{a}$ & $11.68 \mathrm{a}$ & $17.73 \mathrm{a}$ \\
VSP & $3.30 \mathrm{a}$ & $3.03 \mathrm{a}$ & $27.2 \mathrm{a}$ & $25.7 \mathrm{a}$ & $11.25 \mathrm{a}$ & $17.78 \mathrm{a}$ \\
4AK & $3.23 \mathrm{~b}$ & $3.04 \mathrm{a}$ & $27.9 \mathrm{a}$ & $24.9 \mathrm{a}$ & $11.71 \mathrm{a}$ & $17.54 \mathrm{a}$ \\
\hline
\end{tabular}

${ }_{\bar{z}}$ HC: High Cordon; GDC: Geneva Double Curtain; VSP: Vertical Shoot Positioning; 4AK: Four-Arm-Kniffin

$y$ Means followed by the same letter within each column are not significantly different according to a pairwise

$t$-test $(p \leq 0.05)$. 


\section{Discussion}

\subsection{Leaf Removal}

Leaf removal is demonstrated to differentially alter yield, source-sink balance, canopy microclimate, disease incidence, and fruit characteristics depending on timing, severity, location, and cultivar $[8,9,35,38,61-64]$. Cultivars have been documented to respond differently to leaf removal treatments, even at a molecular level [65]. In the current study, many variables were analyzed for a response to leaf removal treatments, yet significant differences were not found in response to leaf removal during either year.

Leaf removal of 'Frontenac' at veraison by Wlordachak et al. (2009) in Illinois yielded no significant differences in fruit composition with leaf removal treatments [57]. A report by Portz et al. (2010) on 'Frontenac Gris' in Iowa found no significant differences in TSS, $\mathrm{pH}$, or TA with leaf removal conducted in early July [56]. Three fruit zone leaf removal levels $(0 \%, 50 \%$, and $100 \%$ ) on 'Frontenac Gris' at three vineyards (near Buffalo, Clifford, and Wahpeton) across eastern North Dakota indicated fruit quality was unaltered by leaf removal in both 2011 and 2012 [66].

'Frontenac Gris' was originally identified as a single bud sport cane found growing on a 'Frontenac' vine at the University of Minnesota Horticulture Research Center. 'Frontenac Gris' has shown similar levels of disease resistance, vigor, productivity, and fruit composition as 'Frontenac' [67]. Therefore, 'Frontenac' and 'Frontenac Gris' may be predisposed to respond similarly to leaf removal treatments, with neither study having a significant response. These prior studies on 'Frontenac' and 'Frontenac Gris' support our findings with a lack of a significant response to leaf removal. As such, the cultivar 'Frontenac' may not respond to leaf removal treatments as monitored by fruit composition under North Dakota climate conditions.

Some research found that leaf removal treatment response could be cultivar-driven and location-dependent. Valenti et al. (2012) found that 'Cabernet Sauvignon' and 'Sangiovese' grown in different locations in Italy, Brisighella, and Scansanco, subjected to the same leaf removal treatments had different results in all analytical parameters [68]. The effectiveness of late leaf removal depended on its final impact on leaf area-to-fruit ration and vine water status, the cultivar photosynthetic compensation capacity, and environmental conditions [69]. Similarly, 'Frontenac' may respond to leaf removal differentially in different areas; however, previous work in Illinois, Iowa, and North Dakota did not show substantial responses as measured by fruit composition.

Interestingly, the early leaf removal treatment in our study did not affect yield components. This could be due to low severity of defoliation, location, winter injury, or a specific response of the cultivar to management tactics. Tardaguila et al. (2008) found that working on both early and late defoliation of five primary basal leaves per shoot had no effect on yield [64]. Yet, Tardaguila's later work in 2010 with early and late defoliation of eight primary basal leaves per shoot had a 30-70\% reduction in yield in early leaf removal [51]. Hence, three basal nodes removal in our research might not be severe enough to trigger a significant response.

\subsection{Training System Effect on Fruit Characteristics}

In our research location in North Dakota with harsh and long winter, temperature and sunlight may play crucial roles in the final grape berry composition. The two most predominant acids in all stages of development representing the most significant influence on acidity and $\mathrm{pH}$ of juice are tartaric and malic acids; they account for $69 \%$ to $92 \%$ of all acids within the grape berries and leaves [40,61]. Tartaric acid is a secondary product formed from the metabolism of glucose ad ascorbate, and its concentration remains relatively stable in the grape as it forms in insoluble salt that is not affected by catabolizable enzymes [70,71]. Malic acid is an active intermediate in grape metabolism; it is accumulated in the vacuole until berries undergo a metabolic shift at veraison, and it is released from the vacuole. Malic acid is a potential source of carbon for respiration, gluconeogenesis, and 
other pathways [70,72]. When the malic acid is metabolized, TA is reduced, influencing the sugar-acid balance [41,70-72].

Though the exact biochemical and molecular mechanisms are yet to be understood for malic degradation, increased temperature post veraison results in increasing malic degradation, and temperature is considered the predominant factor mediating grape malate content at maturity $[40,41,72-74]$. It is known that malate within the berry is synthesized from Phosphoenolpyruvate (PEP) carboxylase and degraded by the malic enzyme. The malic enzyme is much more heat stable than PEP carboxylase [41]. At high temperatures exceeding $30^{\circ} \mathrm{C}$ after veraison, malic enzyme activity rises while PEP carboxylase activity declines [72]. 'Cabernet Sauvignon' had a lower concentration of malic acid in berries developed at $30{ }^{\circ} \mathrm{C}$ than when grown at $20{ }^{\circ} \mathrm{C}$ [72]. 'Shiraz' experiments also found similar results with higher degradation in higher temperatures [73]. Kliewer (1968), using temperature-controlled growth rooms, confirmed that cool conditions typically produce grapes with higher concentrations of organic acids [75].

In North Dakota, only 14 post veraison dates in 2013 reached $30{ }^{\circ} \mathrm{C}$, and only 4 such dates occurred in (NDAWN 2014). This lack of heat may contribute to a lack of observed response in $\mathrm{pH}$ and TA. It may be possible that a subtle amount of malic acid was degraded in 2013, which resulted in a change of $\mathrm{pH}$. The concentration term $\mathrm{pH}$ is a negative logarithmic concentration for free dissociated protons in solution, represents how much acid is in a solution [76]. Losses of small amounts of malic acid may be reflected in the $\mathrm{pH}$. TA, however, is the concentration of free protons and undissociated acids in a solution that can react with a strong base and be neutralized [77]. The TA measurement represents acid strength, and each acid component within the total titratable acidity has a different strength, its tendency to lose its proton. Tartaric acid is stronger than malic acid; thus, when malic acid content changes slightly, TA changes may remain difficult to detect [77]. This might also explain why in 2013, VSP had high pH without significant differences in TA (Table 2).

Smart (1987) states that shading and low $600 \mathrm{~nm} / 730 \mathrm{~nm}$ wavelength ratios penetrating the canopy reduce the activity of the enzyme nitrate reductase, which can lead to an accumulation of nitrate and potassium in the shoots and fruits [38,39,78,79]. Potassium acts as a buffer binding to acids and decreasing the acid strength in solution [80]. The $\mathrm{pH}$ of grape juice results from the balance between anionic forms of organic acids and the major cations. Therefore, alteration of the concentration of any of these factors affects the final $\mathrm{pH}$ of the grape. High concentrations of potassium in juice decrease the concentration of free acids in juice resulting in an overall increase in the $\mathrm{pH}$ [80]. Through this, potassium does not lessen the amount of acids in the solution, just the availability of those protons. However, protons can still be dissociated by a strong base, so the TA remains the same. Therefore, increased $\mathrm{pH}$ and lack of response in TA with VSP treatment might be due to increased shade and potassium.

One explanation for the lack of fruit composition response to treatments could be that no differences in light infiltration occurred between treatments. Due to winter injury, the canopy might be considerably open due to low shoot counts, thus leading to supersaturation with light. Bavaresco et al. (2008) noted that an increase in light infiltration in plants with low canopy density may not significantly affect grape sugar, acidity, and color [55].

To validate treatment effects, PPFD (photosynthetic photon flux density) by Line Quantum Sensor was collected on three occasions each growing season, but the data were unsuitable due to clouds and irregular light measurements. Therefore, point quadrant data were collected once in 2014 to gain insight into canopy structure. Point quadrant data enable the examination of percent gaps in the canopy, leaf layer numbers, percent interior leaves, and percent interior clusters [17]. Percent gaps are optimum between $20 \%$ and $40 \%$, leaf layers optimally between 1.0 and 1.5 or less, interior leaf percentage optimally less than $10 \%$, and percent interior cluster less than $40 \%$ for an optimal canopy [17]. It was found that no significant differences occurred between trellis systems across all measurements (Table A1). However, some treatments were numerically outside of optimal ranges. 
Generally, VSP was the only treatment with optimum values in each measurement, although no treatment had significant differences on point quadrant data. HC and 4AK had fewer gaps compared to the other two, indicating more shade. Interior leaves in each treatment were above the optimum range, except for VSP, which was caused by the dense canopy. The interior cluster percent in VSP was numerically lower than in other treatments.

Research on optimizing 'Frontenac' management via training systems has been very limited. Work by Bavougian et al. (2012) near Crete, NE found increases in yield and brix and decreases in TA when trained to GDC as compared to HC, SD, and VSP in 2008. In the other year of 2009, only yield increased for GDC compared with VSP and HC with no significant differences in fruit composition [18]. Martinson and Particka (n.d), working with 'Frontenac' near Clayton, NY, had results similar to our observations in North Dakota [33]. They had found increased 'Frontenac' yields in Top Wire Cordon (TWC) compared to VSP without causing differences in fruit chemistry in both 2012 and 2013.

\subsection{Training System Effects on Pruning Weights and Node Viability}

Training system treatments and canopy management were more intensely regulated during the years of the study than the previous years. The less intense management in the years prior to the experiment may account for the lack of differences between training system pruning weights in 2013. The following year, 2014, had significant differences with training systems, especially with VSP. The increased growth in VSP could be due to its vertical nature as downward positioned shoots may reduce the vine vigor for the other systems. Downward shoot positioning reduces vine growth and cane diameter and lowers pruning weights due to a narrowing of the xylem vessels reducing sap flow and lower hydraulic conductivity associated with a reduction in stomatal conductance of leaves $[16,81,82]$. Since the VSP vines were the only vines to be positioned vertically, this could account for a larger pruning weight in 2013 and a significantly greater pruning weight in 2014 compared to the other training systems.

Large diameter canes may be less winter hardy and more vigorous; vigorous canopies will often grow late into the fall, and shoots/buds may not properly harden off nor be fruitful [83]. This could account for the greater node mortality in VSP compared to other treatments in 2014. Cordons within the VSP systems are the closest to the ground, and their proximity could result in increased soil radiations on warm days during winter. Without snow cover, VSP may experience more frequent micro warming and cooling compared to other treatments. This could have further caused decreased bud acclimation. In late winter, warm temperatures can promote bud deacclimation, when buds are injured when temperatures return rapidly to normal subzero conditions in winter [84].

As vines deacclimate, biochemical changes occur inside the cells. Vascular plugs are digested by enzymes, allowing water to move into the proximity of the buds. Hormone levels that kept the cells dormant decline, and some cryoprotectants dissipate. This allows the cells to rehydrate and defreeze at higher temperatures $[84,85]$. With higher temperatures, water starts to move into the roots and trunk, and the stored starches are metabolized into sugar and transported into the xylem $[84,86]$. However, when numerous cells are damaged, the structure and function of the vine may be impaired with injured phloem and restricted xylem water and nutrition movement, ultimately leading to shoot collapse [84]. In our research, vines in 2014 had considerably more damage compared to 2013.

Vines on GDC and 4AK systems had significantly higher node viability in the four treatments. GDC and 4AK are both classified as divided canopy systems. Divided canopy systems were designed to reduce vigor and improve sunlight exposure [17]. The increased light penetration into the canopy can further increase periderm formation and carbohydrate storage, which can promote a greater level of freezing tolerance $[11,86]$. This might explain the increased viability of nodes in GDC and 4AK. 


\subsection{Training System Effect on Yield}

Typically, differences in yield between training systems are due to the increased number of nodes and shoot numbers $[11,30,87]$. However, in our research, there were no differences in nodes retained across training systems in 2014. There were no differences in yield in 2013, but there were statistical differences in yield between training systems in 2014. In 2014, GDC and 4AK systems had the highest number of live nodes and the greatest amount of shoots. Interestingly, GDC had a greater yield than VSP treatment, but not statistically greater than HC treatment; even $\mathrm{HC}$ had the shortest cordon length. The differentiation of flowers and shoots, either in fruitful primary buds or less fruitful secondary and tertiary buds, which have a higher rate of survival following extreme winter temperature events, may also contribute to yield differences among canopy management practices [88]. Therefore, different training systems' impact on yield might stem from increased survival of primary buds (Table A2).

\section{Conclusions}

Within our research, leaf removal had no significant effect on 'Frontenac' fruit quality; however, training system selection impacted vine performance across numerous metrics. Due to inconsistent results among different trellis treatments in the two years, more research must focus on choosing the best management practices for 'Frontenac'. Further studies on the effects of canopy management practices to improve fruit quality need to be completed to develop a standard set of recommended viticultural practices for this cultivar and other new cultivars to optimize fruit quality for winemaking for the Upper Midwest and North Dakota producers.

While 'Frontenac' showed no response to leaf removal in our experiments, other grapevine cultivars may be more responsive [66]. Correctly pairing cultivars with management practices will improve fruit and wine composition in cold climates, such as North Dakota. Likewise, although bunch rots were not observed for 'Frontenac' within this experimental period, in the future, leaf removal can be an important tool in reducing rots for low input farming systems with susceptible cultivars [89-91].

Overall, the use of leaf removal practices and trellis system selection remains an important decision for grape growers to make. In other cool climates, such as Wisconsin, exposure of fruit has resulted in the acid reduction in must at harvest [92,93]. Similarly, trellis has demonstrated effects on fruit composition of 'Frontenac' in Nebraska with GDC deemed favorable [2,18]. In this study, 'Frontenac' grape berry components were not substantially altered by management practices; only one occurrence of differences in $\mathrm{pH}$ was attributed to trellis selections. The yield was greatest on GDC trellis in 2014, despite no alteration in target bud number. Growers of 'Frontenac' should account for the lack of measurable benefits from leaf removal (no observed differences in fruit composition or yield attributes during 2013 or 2014) before incorporating them as standard practices in eastern North Dakota.

Author Contributions: Conceptualization, B.K.O., J.S., and H.H.-V.; methodology, B.K.O., J.S., and H.H.-V.; formal analysis, B.K.O., J.S., and H.H.-V.; investigation, B.K.O., M.B., J.S., and H.H.-V.; writing - original draft preparation, B.K.O., Z.W., and H.H.-V.; writing-review and editing, A.S., Z.W., M.B., and H.H.-V.; visualization, A.S. and Z.W.; supervision, project administration, funding acquisition, H.H.-V. All authors have read and agreed to the published version of the manuscript.

Funding: This research was partially funded by the North Dakota Department of Agriculture Specialty Block Grant, grant number 14-SCBGP-ND-0038.

Data Availability Statement: Data is available from the authors upon reasonable request.

Conflicts of Interest: The authors declare no conflict of interest. The funders had no role in the design of the study, in the collection, analyses, or interpretation of data, in the writing of the manuscript, or in the decision to publish the results. 


\section{Appendix A}

Table A1. Point quadrant data collected on the 'Frontenac' grape in Absaraka, ND, in 2014.

\begin{tabular}{ccccc}
\hline Treatment & Gaps $^{\mathbf{z}} \mathbf{( \% )}$ & Leaf Layer $^{\mathbf{y}}$ (No.) & Interior Leaves $^{\mathbf{x}}(\mathbf{\%})$ & Interior Clusters $^{\mathbf{w}}(\mathbf{\%})$ \\
\hline HC $^{\mathrm{v}}$ & $18.6 \mathrm{a}^{\mathrm{u}}$ & $1.3 \mathrm{a}$ & $19.5 \mathrm{a}$ & $24.4 \mathrm{a}$ \\
GDC & $22.2 \mathrm{a}$ & $1.2 \mathrm{a}$ & $18.5 \mathrm{a}$ & $25.2 \mathrm{a}$ \\
VSP & $28.6 \mathrm{a}$ & $0.9 \mathrm{a}$ & $5.8 \mathrm{a}$ & $6.6 \mathrm{a}$ \\
HAK & $18.2 \mathrm{a}$ & $1.3 \mathrm{a}$ & $14.1 \mathrm{a}$ & $30.9 \mathrm{a}$ \\
\hline
\end{tabular}

${ }^{\mathrm{z}}$ Average percentage of canopy that is open and free of plant material per plant (optimum value between $20 \%$ and $40 \%$ ). ${ }^{\mathrm{y}}$ Average leaf layer number per plant equals the number of leaves intercepted by a potential beam of sunlight (optimum value 1.1-1.5 or less). ${ }^{\mathrm{x}}$ Average percentage of leaves interior to the canopy per plant (optimum value $<10.0 \%$ ). ${ }^{\mathrm{w}}$ Average percentage of clusters interior to the canopy of the plant (optimum value < 40.0\%). ${ }^{\text {v }}$ HC: High Cordon; GDC: Geneva Double Curtain; VSP: Vertical Shoot Positioning; 4AK: Four-Arm-Kniffin. ${ }^{\mathrm{u}}$ The same letter within each column are not significantly different according to a pairwise $t$-test $(p \leq 0.05)$.

Table A2. Effect of training system in 2014 on count shoots; primary, secondary, and tertiary-derived shoots in 'Frontenac' grape.

\begin{tabular}{ccccc}
\hline Treatment & Shoot no./Vine & Primary Shoot no./Vine & Secondary Shoot no./Vine & Tertiary Shoot no./Vine \\
\hline $\mathrm{HC}^{\mathrm{z}}$ & $19.4 \mathrm{ab}$ & $3.9 \mathrm{bc}$ & $6.6 \mathrm{bc}$ & $8.9 \mathrm{ab}$ \\
GDC & $24.3 \mathrm{a}$ & $6.6 \mathrm{a}$ & $9.4 \mathrm{a}$ & $7.8 \mathrm{~b}$ \\
VSP & $15.1 \mathrm{~b}$ & $2.3 \mathrm{c}$ & $5.1 \mathrm{c}$ & $7.5 \mathrm{~b}$ \\
$4 \mathrm{AK}$ & $23.0 \mathrm{a}$ & $4.6 \mathrm{ab}$ & $7.9 \mathrm{ab}$ & $10.5 \mathrm{a}$ \\
\hline
\end{tabular}

${ }^{\mathrm{z}}$ HC: High Cordon; GDC: Geneva Double Curtain; VSP: Vertical Shoot Positioning; 4AK: Four-Arm-Kniffin. y The same letter indicates no significant difference according to a pairwise $t$-test $(p \leq 0.05)$.

\section{References}

1. Preston, T.; Ganchiff, M. Frontenac Outgrows Wild Youth, Midwest Wine Press, the Art and Business of Winemaking in the Heartland. 2013. Available online: https:/ / midwestwinepress.com/2013/12/22/frontenac-2/ (accessed on 25 March 2021).

2. Bavougian, C.M.; Read, P.E.; Schlegel, V.L.; Hanford, K.J. Canopy light effects in multiple training systems on yield, soluble solids, acidity, phenol and flavonoid concentration of 'Frontenac' grapes. HortTechnology 2013, 23, 86-92. [CrossRef]

3. Kliewer, W.M.; Howarth, L.; Omori, M. Concentration of tartaric acid and malic acid and their salts in Vitis vinifera grapes. Am. J. Enol. Vitic. 1967, 18, 42-54.

4. Winkler, A.J.; Cook, J.A.; Kliewer, W.M.; Lider, L.A. General Viticulture, 2nd ed.; University of California Press, Ltd.: London, UK, 1974; p. 710.

5. Amerine, M.A.; Berg, H.W.; Cruess, W.V. The Technology of Winemaking; The Avi Publishing Company, Inc.: Westport, CT, USA, 1972.

6. Dami, I.; Bordelon, B.; Ferree, D.C.; Brown, M.; Ellis, M.A.; Williams, R.N.; Doohan, D. Midwest grape production guide. In Bulletin 919; Ohio State University Extension: Columbus, OH, USA, 2005.

7. Archer, E.; Strauss, H.C. Effect of shading on the performance of Vitis vinifera L. cv. Cabernet Sauvignon. S. Afr. J. Enol. Vitic. 1989, 10, 74-77. [CrossRef]

8. Morrison, J.C.; Noble, A.C. The effects of leaf and cluster shading on the composition of Cabernet Sauvignon grapes and on fruit and wine sensory properties. Am. J. Enol. Vitic. 1990, 41, 193-200.

9. Zoecklein, B.W.; Wolf, T.K.; Duncan, N.W.; Judge, J.M.; Cook, M.K. Effects of fruit zone leaf removal on yield, fruit composition, and fruit rot incidence of Chardonnay and White Riesling (Vitis vinifera L.) grapes. Am. J. Enol. Vitic. 1992, 43, 139-148.

10. Katerji, N.; Daudet, F.A.; Carbonneau, A.; Ollat, N. Study at the whole plant level of photosynthesis and transpiration of the vine: Comparison of traditional and lyre training systems. Vitis 1994, 33, 197-203.

11. Reynolds, A.G.; Vanden Heuvel, J.E. Influence of grapevine training systems on vine growth and fruit composition: A review. Am. J. Enol. Vitic. 2009, 60, 251-268.

12. Schultz, H.R. Grape canopy structure, light microclimate and photosynthesis. I. A two dimensional model of the spatial distribution of surface area densities and leaf ages in two canopy systems. Vitis 1995, 34, 211-215. [CrossRef]

13. Smart, R.E.; Dick, J.K.; Gravett, I.M.; Fisher, B.M. Canopy management to improve grape yield and wine quality-principles and practices. S. Afr. J. Enol. Vitic. 1990, 11, 3-17. [CrossRef]

14. Smart, R.E. Sunlight interception by vineyards. Am. J. Enol. Vitic. 1973, 24, 141-147.

15. Smart, R.E.; Dry, P.R.; Bruer, D.R.G. Field temperatures of grape berries and implications for fruit composition. In Proceedings of the International Symposium on the Quality of the Vintage, Cape Town, South Africa, 14-21 February 1977; Huglin, P., Ed.; International Vine and Wine Office: Paris, France; pp. 227-231.

16. Smart, R.E.; Shaulis, N.J.; Lemon, E.R. The effect of Concord vineyard microclimate on yield. I. The effects of pruning, training, and shoot positioning on radiation microclimate. Am. J. Enol. Vitic. 1982, 33, 99-108.

17. Smart, R.E.; Robinson, M. Sunlight into Wine: A Handbook for Winegrape Canopy Management; Winetitles: Underdale, Australia, 1991. 
18. Bavougian, C.M.; Read, P.E.; Walter-Shea, E. Training system effects on sunlight penetration, canopy structure, yield, and fruit characteristics of 'Frontenac' grapevine (Vitis spp.). Int. J. Fruit Sci. 2012, 12, 402-409. [CrossRef]

19. Cawthon, D.L.; Morris, J.R. Yield and quality of Concord grapes as affected by pruning severity, nodes per bearing unit, training system, shoot positioning, and sampling date in Arkansas. J. Am. Soc. Hortic. Sci. 1977, 10, 760-767.

20. Couvillon, G.A.; Nakayama, T.O.M. The effect of the Modified Munson training system on uneven ripening, soluble solids and yield of Concord grapes. J. Am. Soc. Hortic. Sci. 1970, 95, 158-162.

21. Howell, G.S.; Miller, D.P.; Edson, C.E.; Striegler, R.K. Influence of training system and pruning severity on yield, vine size, and fruit composition of Vignoles grapevines. Am. J. Enol. Vitic. 1991, 42, 191-198.

22. Huglin, P. Influence of cultivation practices on the quality of the harvest in temperate regions. In Proceedings of the International Symposium on the Quality of the Vintage, Cape Town, South Africa, 14-21 February 1977; Huglin, P., Ed.; International Vine and Wine Office: Paris, France; pp. 359-372.

23. Morris, J.R.; Cawthon, D.L. Yield and quality response of Concord grapes to training systems and pruning severity in Arkansas. J. Am. Soc. Hortic. Sci. 1980, 105, 307-310.

24. Reynolds, A.G.; Wardle, D.A.; Naylor, A.P. Impact of training system and vine spacing on vine performance and berry composition of Chancellor. Am. J. Enol. Vitic. 1995, 46, 88-97.

25. Reynolds, A.G.; Wardle, D.A.; Naylor, A.P. Impact of training system, vine spacing, and basal leaf removal on Riesling. Vine performance, berry composition, canopy microclimate, and vineyard labor requirements. Am. J. Enol. Vitic. 1996, 47, 63-76.

26. Shaulis, N.J.; Amberg, H.; Crowe, D. Responses of Concord grapes to light, exposure and Geneva double curtain training. Proc. Am. Soc. Hortic. Sci. 1966, 89, 268-280.

27. May, P.; Clingeleffer, P.R.; Brien, C.J. Sultana (Vitis vinifera L.) canes and their exposure to light. Vitis 1976, 14, 278-288. [CrossRef]

28. Peterlunger, E.; Celotti, E.; Da Dalt, G.; Stefanelli, S.; Gollino, G.; Zironi, R. Effect of training system on Pinot noir grape and wine composition. Am. J. Enol. Vitic. 2002, 53, 14-18.

29. Reynolds, A.G.; Wardle, D.A.; Cliff, M.A.; King, M. Impact of training system and vine spacing on vine performance, berry composition, and wine sensory attributes of Seyval and Chancellor. Am. J. Enol. Vitic. 2004, 55, 84-95.

30. Shaulis, N.J.; May, P. Response of 'Sultana' vines to training on a divided canopy and to shoot crowding. Am. J. Enol. Vitic. 1971, 22, 215-222.

31. Van Zyl, J.L.; van Huyssteen, L. Comparative studies on wine grapes on different trellising systems: II. Microclimatic studies, grape composition, and wine quality. S. Afr. J. Enol. Vitic. 1980, 1, 15-25. [CrossRef]

32. Wolf, T.K.; Dry, P.R.; Iland, P.G.; Botting, D.; Dick, J.; Kennedy, U.; Ristic, R. Response of Shiraz grapevines to five different training systems in the Barossa Valley, Australia. Aust. J. Grape Wine Res. 2003, 9, 82-95. [CrossRef]

33. Martinson, T.E.; Particka, C.A. Frontenac Training Trial Viticulture Enology and Marketing for Cold-Hardy Grapes. Northern Grapes Project. Web. 8 June 2015. Available online: http://northerngrapesproject.org/wp-content/uploads/2014/02/ NyFrontTrain.pdf (accessed on 10 March 2021).

34. Coombe, B.G. Fruit set and development in seeded grape varieties as affected by defoliation, topping, girdling and other treatments. Am. J. Enol. Vitic. 1959, 10, 85-100.

35. Crippen, D.; Morrison, J. The effects of sun exposure on the compositional development of Cabernet Sauvignon berries. Am. J. Enol. Vitic. 1986, 37, 235-242.

36. Hunter, J.J.; de Villiers, O.T.; Watts, J.E. The effect of partial defoliation on quality characteristics of Vitis vinifera L. cv. Cabernet Sauvignon Grapes. I. Sugars, acids and pH. S. Afr. J. Enol. Vitic. 1991, 12, 42-50. [CrossRef]

37. Gaprindashvili, G.V. Sugar and acid content of grapevine berries as influenced by exposure to light (Russ.) Sadovod. Vinograd. Vinodel. Mold. 1981, 36, 52-53.

38. Percival, D.C.; Fisher, K.H.; Sullivan, J.A. Use of fruit zone leaf removal with Vitis vinifera L. cv. Riesling grapevines. II. Effect on fruit compostion, yield, and occurence of bunch rot (Botrytis cinerea Pers.:Fr.). Am. J. Enol. Vitic. 1994, 45, $133-140$.

39. Bledsoe, A.M.; Kliewer, W.M.; Marois, J.J. Effects of timing and severity of leaf removal on yield and fruit composition of Sauvignon blanc grapevines. Am. J. Enol. Vitic. 1988, 39, 49-54.

40. Lakso, A.N.; Kliewer, W.M. The influence of temperature on malic acid metabolism in grape berries. Plant Physiol. 1975, 56, 370-372. [CrossRef] [PubMed]

41. Lakso, A.N.; Kliewer, W.M. The influence of temperature on malic acid metabolism in grape berries. II. Temperature responses of net dark $\mathrm{CO}_{2}$ fixation and malic acid pools. Am. J. Enol. Vitic. 1978, 29, 145-149.

42. Reynolds, A.G.; Pool, R.M.; Mattick, L.R. Influence of cluster exposure on fruit composition and wine quality of Seyval blanc grapes. Vitis 1986, 25, 85-95. [CrossRef]

43. Kliewer, W.M.; Antcliff, A.J. Influence of defoliation, leaf darkening, and cluster shading on the growth and composition of sultana grapes. Am. J. Enol. Vitic. 1970, 21, 26-36.

44. Acimovic, D.; Tozzini, L.; Green, A.; Sivilotti, P.; Sabbatini, P. Identification of a defoliation severity threshold for changing fruitset, bunch morphology and fruit composition in Pinot Noir. Aust. J. Grape Wine Res. 2016, 22, 399-408. [CrossRef]

45. Bubola, M.; Sivilotti, P.; Janjanin, D.; Poni, S. Early leaf removal has larger effect than cluster thinning on cv. Teran grape phenolic composition. Am. J. Enol. Vitic. 2017, 68, 234-242.

46. Caspari, H.W.; Lang, A. Carbohydrate supply limits fruit-set in commercial Sauvignon Blanc grapevines. In Proceedings of the 4th International Cool Climate Viticulture Symposium, Rochester, NY, USA, 16-20 July 1996; pp. 9-13. 
47. Vasconcelos, M.C.; Greven, M.; Winefield, C.S.; Trought, M.C.T.; Raw, V. The flowering process of Vitis vinifera: A review. Am. J. Enol. Vitic. 2009, 60, 411-433.

48. Moreno, D.; Valdés, E.; Uriarte, D.; Gamero, E.; Talaverano, I.; Vilanova, M. Early leaf removal applied in warm climatic conditions: Impact on Tempranillo wine volatiles. Food Res. Int. 2017, 98, 50-58. [CrossRef]

49. Poni, S.; Casalini, L.; Bernizzoni, F.; Civardi, S.; Intrieri, C. Effects of early defoliation on shoot photosynthesis, yield components, and grape composition. Am. J. Enol. Vitic. 2006, 57, 397-407.

50. Reynolds, A.G.; Wardle, D.A.; Hall, J.W.; Dever, M. Fruit maturation of four Vitis vinifera cultivars in response to vineyard location and basal leaf removal. Am. J. Enol. Vitic. 1995, 46, 542-558.

51. Tardáguila, J.; de Toda, F.M.; Poni, S.; Diago, M.P. Impact of early leaf removal on yield and fruit and wine composition of Vitis vinifera L. Graciano and Carignan. Am. J. Enol. Vitic. 2010, 61, 372-381.

52. Iland, P.G. Leaf removal effects on fruit composition. In Proceedings of the Second International Symposium for Cool Climate Viticulture and Oenology, Auckland, New Zealand, 11-15 January 1988; pp. 137-138.

53. Jackson, D.I.; Lombard, P.B. Environment and management practices affecting grape composition and wine quality-A review. Am. J. Enol. Vitic. 1993, 44, 409-430.

54. Norton, K.E. Effect of Leaf Removal on Grape Composition of Chardonnay in Oregon. Master's Thesis, Oregon State University, Corvallis, OR, USA, 1987.

55. Bavaresco, L.; Gatti, M.; Pezzutto, S.; Fregoni, M.; Mattivi, F. Effect of leaf removal on grape yield, berry composition, and stilbene concentration. Am. J. Enol. Vitic. 2008, 59, 292-298.

56. Portz, D.N.; Riesselman, L.B.; Seeley, C.; Beamer, P.; Nonnecke, G.R. Effects of Leaf Removal on Fruit Quality of Wine Grapes Grown in Iowa; Iowa State Research Farm Progress Reports; Iowa State University: Ames, IA, USA, 2010; p. 140. Available online: http:/ /lib.dr.iastate.edu/farms_reports/140 (accessed on 20 December 2020).

57. Wlordachak, N.; Kushad, M.; Elgargoti, A. Influence of leaf removal before veraison on sugar and organic acids in three wine grape cultivars. In Transactions of the Illinois Horticulture Society and the 13th Annual Illinois Fruit and Vegetable Crops Research Report; University of Illinois Extension and the College of Agricultural, Consumer, and Environmental Sciences, University of Illinois: Urbana-Champaign, IL, USA, 2009; Volume 143, pp. 80-86.

58. Martin, S.R.; Dunn, G.M. Effect of pruning time and hydrogen cyanamide on bud break and subsequent phenology of Vitis vinifera L. variety Cabernet Sauvignon in central Victoria. Aust. J. Grape Wine Res. 2000, 6, 31-39. [CrossRef]

59. Ravaz, L. Taille Hative ou Taille Tardive; Coulet et Fils Editeurs, Libraires de L'Ecole Nationale D'Agriculture: Montpellier, France, 1912.

60. Wolpert, J.A.; Howell, G.S. Effects of cane length and dormant season pruning date on cold hardiness and water content of concord bud and cane tissues. Am. J. Enol. Vitic. 1984, 35, 237-241.

61. Morris, J.R.; Sims, C.A.; Cawthon, D.L. Effects of excessive potassium levels on pH, acidity and color of fresh and stored grape juice. Am. J. Enol. Vitic. 1983, 34, 35-39.

62. Arnold, R.A.; Bledsoe, A.M. The effect of various leaf removal treatments on the aroma and flavor of Sauvignon blanc wine. Am. J. Enol. Vitic. 1990, 4, 74-76.

63. Dry, P.R. Canopy management for fruitfulness. Aust. J. Grape Wine Res. 2000, 6, 109-115. [CrossRef]

64. Tardaguila, J.; Diago, M.P.; Martinez de Toda, F.; Poni, S.; Vilanova, M. Effects of timing of leaf removal on yield, berry maturity, wine composition and sensory properties of cv. Grenache grown under non irrigated conditions. J. Int. Sci. Vigne Vin. 2008, 42, 221-229. [CrossRef]

65. Zenoni, S.; Dal Santo, S.; Tornielli, G.B.; D’Incà, E.; Filippetti, I.; Pastore, C.; Allegro, G.; Silvestroni, O.; Lanari, V.; Pisciotta, A.; et al. Transcriptional responses to pre-flowering leaf defoliation in grapewine berry from different growing sites, years and genotypes. Front. Plant Sci. 2017, 8, 630. [CrossRef]

66. Aipperspach, A.; Hammond, J.; Hatterman-Valenti, H. Utilizing pruning and leaf removal to optimize ripening of Vitis ripariabased 'Frontenac Gris' and 'Marquette' wine grapes in the northern great plains. Horticulture 2020, 6, 18. [CrossRef]

67. Luby, J.; Hemstad, P. A Grapevine Named 'Frontenac Gris'. U.S. Plant Patent No. PP16, 478, 25 March 2006.

68. Valenti, L.; Ghiglieno, I.; Mattivi, F. Effect of leaf removal on grapes of Cabernet sauvignon and Sangiovese cultivated in different Italian environments. J. Food Sci. Eng. 2012, 2, 719-726. [CrossRef]

69. Buesa, I.; Caccavello, G.; Basile, B.; Merli, M.C.; Poni, S.; Chirivella, C.; Intrigliolo, D.S. Delaying berry ripending of Bobal and Tempranillo grapevines by late leaf removal in a semi-arid and temperate-Warm climate under different water regimes. Aust. J. Grape Wine Res. 2019, 25, 70-82. [CrossRef]

70. Ruffner, H.P. Metabolism of tartaric and malic acids in Vitis: A review part b. Vitis 1982, 21, 346-358. [CrossRef]

71. Saito, K.; Kasai, Z. Accumulation of tartaric acid in the ripening process of grapes. Plant Cell Physiol. 1968, 9, 529-537. [CrossRef]

72. Buttrose, M.S.; Hale, C.R.; Kliewer, W.M. Effect of temperature on the composition of Cabernet Sauvignon berries. Am. J. Enol. Vitic. 1971, 22, 71-75.

73. Sweetman, C.; Sadras, V.O.; Hancock, R.D.; Soole, K.L.; Ford, C.M. Metabolic effects of elevated temperature on organic acid degradation in ripening Vitis vinifera fruit. J. Exp. Bot. 2014, 65, 5975-5988. [CrossRef] [PubMed]

74. Ruffner, J.P.; Hawker, J.S.; Hale, C.R. Temperature and enzymic control of malate metabolism in berries of Vitis Vinifera. Phytochemistry 1976, 15, 1877-1880. [CrossRef]

75. Kliewer, W.M. Effect of temperature on the composition of grapes grown under field and controlled conditions. Proc. Am. Soc. Hortic. Sci. 1968, 93, 797-806. 
76. Boulton, R. The relationship between total acidity, titratable acidity and $\mathrm{pH}$ in wine. Am. J. Enol. Vitic. 1980, 31, 76-80.

77. Amerine, M.A.; Roessler, E.B.; Ough, C.S. Acids and the taste. 1) The effect of $\mathrm{pH}$ and titratable acidity. Am. J. Enol. Vitic. $1965,16,29-37$.

78. Smart, R.E. Influence of light on composition and quality of grapes. Acta Hortic. 1987, 206, 37-47. [CrossRef]

79. Macaulay, L.E.; Morris, J.R. Influence of cluster exposure and winemaking processes on monoterpenes and wine olfactory evaluation of Golden Muscat. Amer. J. Enol. Vitic. 1993, 44, 198-204.

80. Kodur, S. Effects of juice $\mathrm{pH}$ and potassium on juice and wine quality, and regulation of potassium in grapevines through rootstocks (Vitis): A short review. Vitis 2011, 50, 1-6. [CrossRef]

81. Schubert, A.; Lovisolo, C.; Peterlunger, E. Sap flow and hydraulic conductivity of grapevine shoots trained to the upward or downward position. In Proceedings of the Fourth International Symposium on Cool Climate Enology and Viticulture. T., Rochester, NY, USA, 16-20 July 1996.

82. Lovisolo, C.; Schubert, A. Downward shoot positioning affects water transport in field-grown grapevines. Vitis 2000, 39, 49-53. [CrossRef]

83. Wilwerth, J.; Ker, K.; Inglis, D. Best Management Practices for Reducing Winter Injury in Grapevines; Brock University: St. Catharines, ON, Canada, 2014.

84. Fennell, A. Freezing tolerance and injury in grapevines. J. Crop. Improv. 2004, 10, 201-235. [CrossRef]

85. Ker, K.; Brewster, R. What does Deacclimation Mean to Me. 2011. Available online: https://brocku.ca/webfm_send/16138 (accessed on 5 November 2017).

86. Wolpert, J.A.; Howell, G.S. Cold acclimation of Concord grapevines. III. Relationship between cold hardiness, tissue water content, and maturation. Vitis 1986, 25, 151-159. [CrossRef]

87. Liu, M.Y.; Chi, M.; Tang, Y.H.; Song, C.Z.; Xi, Z.M.; Zhang, X.W. Effect of three training systems on grapes in a wet region of China: Yield, incidence of disease and anthocyanin compositions of Vitis vinifera cv. Cabernet Sauvignon. Molecules 2015, 20, 18967-18987. [CrossRef]

88. Sanchez, L.A.; Dokoozlian, N.K. Bud microclimate and fruitfulness in Vitis vinifera L. Am. J. Enol. Vitic. 2005, 56, 319-329.

89. VanderWeide, J.; Frioni, T.; Ma, Z.; Stoll, M.; Poni, S.; Sabbatini, P. Early leaf removal as a strategy to improve ripening and lower cluster rot in cool climate (Vitis vinifera L.) Pinot grigio. Am. J. Enol. Vitic. 2020, 71, 70-79. [CrossRef]

90. Vogel, A.R.; White, R.S.; MacAllister, C.; Hickey, C.C. Fruit Zone Leaf Removal Timing and Extent Alters Bunch Rot, Primary Fruit Composition, and Crop Yield in Georgia-grown 'Chardonnay' (Vitis vinifera L.). HortScience 2020, 55, 1654-1661. [CrossRef]

91. VanderWeide, J.; Gottschalk, C.; Schultze, S.R.; Nasrollahiazar, E.; Poni, S.; Sabbatini, P. Impacts of Pre-bloom Leaf Removal on Wine Grape Production and Quality Parameters: A Systematic Review and Meta-analysis. Front. Plant Sci. 2020, 11. [CrossRef]

92. Scharfetter, J.; Workmaster, B.A.; Atucha, A. Preveraison leaf removal changes fruit zone microclimate and phenolics in cold climate interspecific hybrid grapes grown under cool climate conditions. Am. J. Enol. Vitic. 2019, 70, 297-307. [CrossRef]

93. Riesterer-Loper, J.; Workmaster, B.A.; Atucha, A. Impact of fruit zone sunlight exposure on ripening profiles of cold climate interspecific hybrid winegrapes. Am. J. Enol. Vitic. 2019, 70, 286-296. [CrossRef] 